\title{
Esperanza López Parada, El botón de seda negra, tradición religiosa y cultura material en las Indias. Madrid-Frankfurt, Iberoamericana- Vervuert, 2018, 428 páginas
}

\section{Valeria Añón}

Cita sugerida: Añón, V. (2020). [Revisión del libro El botón

de seda negra, tradición religiosa y cultura material en las

Indias por E. López Parada]. Orbis Tertius, 25(32), e188.

https://doi.org/10.24215/18517811e188

En los últimos años, los estudios literarios coloniales se han visto renovados a partir del cruce con los estudios visuales, los estudios sobre cultura material, las nuevas inflexiones del giro espacial, entre otras perspectivas. Así, el objeto literario colonial se complejiza y las preguntas a las que es sometido saturan otras dimensiones de las representaciones y las prácticas. Esto ocurre en tensión con los interrogantes en torno a lo colonial y la colonialidad, y a sus polémicas. Se trata, en resumen, de un campo en constante ampliación y debate, que disputa espacios de enunciación diversos (por novedosos) para la crítica. El botón de seda negra surge en el corazón de estos cruces y busca contribuir de manera significativa a ellos, a partir de una mirada renovada en las dimensiones teórica, metodológica y analítica. Los objetivos (y los objetos) del libro son múltiples, caleidoscópicos, heterogéneos, aunque los rige (y reúne) la compleja articulación entre traducción religiosa y cultura material que se postula ya desde el título. Como la traducción poscolonial, en su doble tensión de imposición y resistencia, este libro opera entre la metonimia y la metáfora, de allí el objeto que lo encabeza, ese botón de seda negra que opera por contigüidad y señalamiento, pero también por alegórica significación, el vínculo entre archivo colonial y mirada crítica. En este sentido, el libro funciona por referencia y desplazamiento, es decir, remite a dimensiones fundamentales en el campo y, a la vez, produce una torsión crítica que conduce a mirar aquello que había permanecido oculto o poco atendido, o bien que 
parecía agotado en sus posibilidades de interpretación. El volumen funciona articulando un derrotero crítico que deslumbra por inesperado, que encanta por sabroso, que renueva porque mira desprejuiciadamente sus problemas. Tres dimensiones definen y singularizan este notable volumen, y le confieren un lugar destacado: la traducción, los objetos, el archivo.

Preocupación de larga data en los estudios coloniales, la traducción ha sido concebida en la tensión entre imposiciones, negociaciones y resistencias, con cierta tendencia, en los últimos años, a enfatizar la segunda. Este libro retoma estos debates para centrarse en uno de sus ejes, la traducción religiosa, sintagma de compleja caracterización que define tanto una dinámica como concepciones de lengua, de comunicación, de subjetividad. En la tensión entre inteligibilidad e irreductibilidad se erige toda traducción, pero esto es especialmente aguzado en el contexto colonial temprano andino y novohispano (siglo XVI, principios del XVII), cuando toda comunicación es problema, posibilidad, promesa. Y también diferencia. De hecho, diversidad y diferencia constituyen los modos específicos de pensar la traducción que este libro propone, de allí que se afirme que "el presente estudio considera a la traducción desde un amplio espectro como forma privilegiada de la transferencia, pero también como un sistema de detección de diferencia entre el Nuevo y el Viejo Mundo” (p. 29). Aquí, traducir será acercar, descifrar, aprehender. Pero también será operar con los límites, los resabios, los imposibles de la traducción y la experiencia. En efecto, experiencia y traductibilidad están reunidos en cada operación traslaticia interlingüística e intersemiótica, y en cada objeto que metonímicamente las señala, y constituyen problema central en las concepciones de este Nuevo Mundo, de estas Indias. Claro que esta traducción es religiosa, lo cual suma nuevas aristas a un tema clásico. Nuevas en el sentido de su complejidad, pero también de su especificidad: se trata de traducir dogmas, fe, creencias, pero también de intraducir un sistema otro que tanto fascina como repulsa la mirada eurocéntrica. Traducción y cristiandad, íntimamente ligadas, están también íntimamente regladas, como forma de controlar la expansión significante que el intercambio propicia, e incluso como forma de ordenar la experiencia. Traducir es domesticar, volver inteligible, transportable, manejable. La traducción religiosa reviste, así, objetivos epistemológicos y performativos; busca operar sobre cosmovisiones y sobre conductas, e identificar el corazón de las creencias autóctonas para desactivarlas. La autora desmenuza, con pericia crítica, los espacios textuales, materiales y experienciales donde estas operaciones se despliegan: sermonarios, diccionarios, gramáticas, vocabularios como materiales significantes exhiben los pertinaces esfuerzos de aprehensión e inteligibilidad, y atraviesan de manera transversal todos los capítulos, porque el objeto no es un autor, una obra, un problema, sino mecanismos, dinámicas, dimensiones de la representación como operación de la diferencia. Quizá por ello descollan aquellos capítulos en los cuales se piensa la compleja traducción del nombre del Dios $(3,4,6)$ y del dogma $(7)$ : más allá de los denodados esfuerzos de trasposición e interpretación, lo que se despliega es la traducción como imposibilidad y, al mismo tiempo, como certeza: una suerte de tarea de Sísifo que define al archivo americano.

Para dar cuenta de estas aristas, la autora erige un inventario propio, heterogéneo y heteróclito, en el cual reside uno de sus mayores hallazgos. En diferentes momentos el libro remite al museo, la colección, los gabinetes de maravillas, las Wunderkammern... Incluso, con Eco, se atreve a definir al museo, en su voracidad, a partir de un gesto de rapiña (cap. 12). Estas imágenes inquietantes (porque en la maravilla anida lo monstruoso y lo disforme) reverberan en la definición de este libro que, sin embargo, excede cada una de estas nociones, dimensiones, objetos. Confluye aquí la concepción compleja y heterogénea de "cultura material" que el libro organiza desde sus primeras páginas, a partir de una argumentación rizomática que, no obstante, no resulta opaca para el lector, sino atractiva. Cada capítulo despliega textualidades diversas (desde las crónicas y las historias hasta los sermonarios o diccionarios ya mencionados), reunidas junto a objetos y prácticas que encantan por disímiles e inesperados: la confesión por quipus (cap. 5); la coca como alimento, práctica diferenciadora, límite de la transculturación (cap. 8) o incluso la "comunión (no) administrada a los indios" (cap. 9), reverso en un sentido de la costumbre de mascar coca, en la medida en que las metáforas digestivas sirven para mostrar estrategias de jerarquización, subalternización o configuración 
de nuevas subjetividades. Así de complejo y de creativo es lo que estas escenas, marginales en alguna medida en los estudios literarios coloniales, ofrecen a la mirada crítica sutil que El botón de seda negra enhebra. Más que colección, museo o gabinete de maravillas, el heteróclito corpus de este libro construye una suerte de encantador árbol de la vida, ese artefacto de barro característico del centro de México, que fue usado en primera instancia como herramienta de evangelización, pero que luego, por efecto de diversas apropiaciones transculturadoras, pasó a identificarse también con un espacio y una sensibilidad autóctonas. Objeto que reúne materiales e historias heterogéneos y bellos, mínimos y majestuosos, sacros y profanos, coloridos y densos; que entronca tradiciones en varios ejes, sintagmático y paradigmático, y recurre a asociaciones insólitas, imprevistas. Extremando la metáfora, quizás uno de los mayores hallazgos críticos de este libro sea la mirada desprejuiciada con que acude al archivo indiano para desorganizarlo, descentrarlo, y producir así un artefacto crítico de precisa e inesperada factura.

La imagen arriba aludida nos permite ingresar aquí a otra de las dimensiones centrales de este libro, la del archivo. Enmarcado en una investigación colectiva mayor, con un proyecto interinstitucional e internacional denominado ELBA ("En los bordes del archivo"), El botón de seda negra ofrece una mirada desplazada acerca del archivo colonial como objeto y acerca del archivo crítico que lo desmenuza o celebra. En términos de objeto, ya desde la introducción la autora afirma estar operando en los márgenes del archivo colonial, allí donde aquello menos atendido literariamente (listados, inventarios, vocabularios, quipus, huacas) permite plantear otro tipo de dilemas, que no se limitan a la circulación o a la materialidad, sino que interrogan el sentido, la representación. Atender a los márgenes, a los bordes, constituye una apuesta crítica de complejización del archivo y una apuesta hermenéutica de desciframiento de sus silencios y secretos. Claro que estos márgenes solo tienen sentido o se constituyen como tales en la sinergia de una lectura con materiales centrales, canónicos, como los Comentarios Reales del Inca Garcilaso, la Nueva corónicaybuen gobierno de Felipe Guaman Poma de Ayala o los papeles de Polo de Ondegardo, por nombrar solo tres de los más conocidos. Lo interesante es que, como resultado de una fuerza centrípeta de los bordes al centro, incluso estos "clásicos" se ven renovados en esta lectura, porque se les propone otros sistemas en los que operar sus sentidos, otros diálogos posibles, lejos de una serie que los organice simplemente en términos de resistencia o de imposición. En esta dimensión se destaca también el trabajo con la crítica y la teoría (colonial, poscolonial, literaria, histórica), que deslumbra por su amable erudición. Podríamos definir la posición crítica que este libro construye como una mirada curiosa, lúdica en un punto, que elude los límites del archivo crítico metropolitano porque se permite discutir con él. No se trata de plantear un estado de la cuestión de cada dimensión o derrotero que el volumen toma, sino de acudir, con avidez, a aquello que, mucho o poco, cada perspectiva puede aportar. Se organiza entonces una trama de conceptos, categorías, reflexiones que resulta provocadora para el lector, desafiante, y que consigue el mejor de los efectos: conducirnos a la reflexión y a plantearnos nuevas preguntas.

Claro que todo esto se logra a partir de una premisa crucial: una exquisita escritura. La autora de este volumen también es poeta, y ese vínculo precioso con la palabra y el detalle define la sutileza de su propuesta. Se trata de un libro que no olvida al lector, sino que lo coloca en su centro; que busca deleitarlo, atraerlo, atraparlo con la curiosidad de sus hallazgos y la siempre imprevisible asociación que enhebra cada uno de sus capítulos y dimensiones. Para ello, y más allá de la hondura categorial y analítica, el libro apela a una retórica sensible que entrelaza imágenes y escenas visuales, auditivas, táctiles, para reconstruir, en la desafiante sintagmática de la escritura, la densidad del "objeto indiano" u "objeto colonial", que aparece definido como categoría en el último capítulo, pero que se ha ido desplegando, indicialmente, en cada uno de los análisis. Esta experiencia de lectura es una experiencia intelectual y afectiva a un tiempo, y ese es quizá uno de los mayores logros de este botón de seda negra: el sabor de una escritura crítica deslumbrante que perdura más allá de sus páginas. 